\title{
Characterization of Wheat Flour Bread Fortified with Banana Flour
}

\author{
Towhidur Rahman ${ }^{1, *}$, Shompa Akter ${ }^{2}$, Ashfak Ahmed Sabuz ${ }^{3}$, Rahmatuzzaman Rana ${ }^{4}$ \\ ${ }^{1}$ Upazila Nirbahi Officer (Chief Administrative Officer of a Sub-District), Fulbari, Kurigram, Bangladesh. \\ ${ }^{2}$ Upazila Agriculture Officer (Chief Agriculture Officer of a Sub-District), Rajarhat, Kurigram, Bangladesh. \\ ${ }^{3}$ Scientific Officer, Postharvest Technology Division, Bangladesh Agricultural Research Institute, Gazipur, Bangladesh. \\ ${ }^{4}$ Assistant Professor, Food Engg. \& Tea Technology, Shahjalal University of Science \& Technology, Sylhet, Bangladesh.
}

\begin{abstract}
How to cite this paper: Towhidur Rahman, Shompa Akter, Ashfak Ahmed Sabuz, Rahmatuzzaman Rana. (2021) Characterization of Wheat Flour Bread Fortified with Banana Flour. International Journal of the Science of Food and Agriculture, 5(1), 7-11.

DOI: 10.26855/ijfsa.2021.03.002

Received: December 7, 2020

Accepted: December 31, 2020

Published: January 7, 2021

*Corresponding author: Towhidur Rahman, Upazila Nirbahi Officer (Chief Administrative Officer of a Sub-District), Fulbari, Kurigram, Bangladesh.

Email: towhidbau@gmail.com
\end{abstract}

\begin{abstract}
Breads were formulated from wheat flour incorporating 5\%, 10\%, and 15\% banana flour. The baking properties of bread, such as loaf volume, specific volume, and moisture content, were evaluated. The proximate composition of the formulated bread was analyzed. Bread volume decreased with increasing banana flour, whereas the bread weight and moisture content significantly increased with the increasing level of banana flour. It was a noticeable observation that the ash content increased in a noticeable amount by increasing the proportion of banana flour. The color of both crumb and crust of bread was improved by incorporating $5 \%$ banana flour in bread formulation. The analysis of bread containing 5\% banana flour showed moisture $33.55 \%$, Protein $8.575 \%$, fat $2.60 \%$, ash $1.59 \%$, crude fiber $1.20 \%$, total sugar $1.75 \%$, carbohydrate $53.685 \%$, respectively. The formulation of banana blend (5\%) bread was wheat flour 190g, banana flour 10g, yeast 4g, sugar 8g, salt 4g, fat 8g, moisture $130 \mathrm{ml}$. Semi-trained panelists carried out the sensory analysis. The response of the taste panelist was statistically analyzed. The flavor, color, and overall acceptability of bread containing $5 \%$ banana flour give the highest average score value. The bakery industry may use banana flour for incorporation into the bread making without much affecting the sensory qualities with improved fiber contents.
\end{abstract}

\section{Keywords}

Bread, Banana, Sensory Evaluation, Banana Flour

\section{Introduction}

Banana (Musa paradisiaca, Musaceae family) has a high nutrient value and is one of the world's most common fruits. Banana shows high flavonoids, dietary fibre (DF), and stubborn starch (RS) than when ripe at the early stages [1]. It is probably one of the oldest grown crops in the world. Banana is consumed in many ways and has many dietary and therapeutic advantages. Ripe bananas are used in various ways in our human diet, from simply peeling and eating out of hand to cutting and serving in fruit bowls and salads, sandwiches, custards, and gelatines mashed into ice cream, bread, muffins, and cream bread.

In Bangladesh, the popularity of bread is growing, and they are not limited to higher-income groups alone. Bread is easier for various formulations to fulfil a wide variety of market demands about taste and nutrition. Highly nutritious banana bread is a common food supplier to vulnerable groups of pregnant mothers, young schools, and kids [2]. Also, bread is consumed worldwide, contributing particularly in developing countries to the consumption of proteins, lipids, and carbohydrates. Thus, banana flour has an excellent opportunity to improve bread and increase its nutritious value. Although the market offers a wide variety of bread styles, white bread still represents the first option for many customers because of its sensory qualities. The high percentage of rapidly digested starch (RDS), which correlates positively 
with the in vivo postprandial glycaemic index (pGI) after 20 minutes of digestion, is considered a high glycaemic food [3]. The addition of banana flour in the bread can increase the bread's nutritional quality, which directly benefits Bangladesh's malnutrition problem. Based on information so far accumulated, the present study has been undertaken to achieve the optimum formulation of bread incorporating various banana flour and evaluating the baking quality and sensory features of those.

\section{Methods}

This study was carried out in Food Technology and Rural Industries Department laboratories, Bangladesh University of Agriculture, Mymensingh, Bangladesh.

\subsection{Materials}

\subsubsection{Banana flour/powder}

Uniformly mature ripen bananas were collected from the local market. Then, the bananas were peeled and screened through a mesh to remove off fibrous portion. After that, the foaming agent (albumen) was added at the rate of $5 \%$ by weight of the mashed banana and mixed until the fine foam was obtained. This process was done promptly to avoid any browning or discoloration. The fine banana foam was spread on a tray and dried at $55^{\circ} \mathrm{C}$ in a cabinet drier until it became suitable for making flour. The dried sample ground into fine banana flour and stored at $40 \mathrm{C}$ until further use.

\subsubsection{Wheat flour (Maida)}

Commercially available wheat flour (Maida) was collected from the local market and used in bread preparation.

\subsubsection{Formulation for bread from banana flour}

A different proportion of banana flour replaced the wheat flour. The formulation of banana blend bread is outlined in Table 1.

\subsubsection{Procedure for bread preparation}

The bread was made according to the method described by Kent (1994) [4]. The yeast was initially rehydrated (8 ml of water/g of yeast) in warm water $\left(40^{\circ} \mathrm{C}\right)$ for 10 minutes to start fermentation. Sugar and salt were dissolved in a measured amount of water. All the ingredients were mixed for about 10 minutes to prepare control and fortified bread. The prepared dough was left 2 hours away to allow the fermentation process. To avoid dehydration, the dough was coated with moistened fabric. Upon two hours of fermentation, the gas involved was "knocked out" so that the temperature could stand, and the thorough mixing could be carried out. After 1 hour of resting, the dough is divided into roughly shaped loaf size (i.e., $200 \mathrm{gm}$ ). The dough pieces were rested at around $27^{\circ} \mathrm{C}$ for $10-15$ minutes (1st proof) and shaped into final form to tighten the dough mechanically so that the gas and water could better spread, be stored, and placed in pre-greased baking cups. The dough was again rested in the baking pan for the final tests at $370^{\circ} \mathrm{C}$ for $60 \mathrm{mi}-$ nutes and then baked for 40 minutes at temperature $230^{\circ} \mathrm{C}$ in the oven. The loaves were allowed to cool for a minimum of $2 \mathrm{hr}$. at $24^{\circ} \mathrm{C}$ before evaluation.

Table 1. Formulation of banana blend bread

\begin{tabular}{|c|c|c|c|c|}
\hline \multirow[t]{2}{*}{ Ingredients } & \multicolumn{4}{|c|}{ Samples } \\
\hline & $\mathrm{S}_{1}$ & $\mathrm{~S}_{2}$ & $\mathrm{~S}_{3}$ & $\mathrm{~S}_{4}$ (Control) \\
\hline Wheat flour (g) & 170 & 180 & 190 & 200 \\
\hline Banana Flour (g) & 30 & 20 & 10 & 0 \\
\hline Yeast (g) & 4 & 4 & 4 & 4 \\
\hline Sugar (g) & 8 & 8 & 8 & 8 \\
\hline Salt (g) & 4 & 4 & 4 & 4 \\
\hline Fat (g) & 8 & 8 & 8 & 8 \\
\hline Water (ml) & 130 & 130 & 130 & 130 \\
\hline *Bread Improver & 1.00 & 1.00 & 1.00 & 1.00 \\
\hline
\end{tabular}

*Bread improver = potassium bromate $0.30 \mathrm{~g}$, ascorbic acid $0.50 \mathrm{~g}$; calcium sulfate $7.50 \mathrm{~g}$; ammonium chloride $8 \mathrm{~g}$ and malt flour $36.70 \mathrm{~g}$ for good quality bread.

\subsection{Evaluation of physical characteristics of bread}

Initially, the volume of the bread is an important quality parameter. The seed transfer method, defined by Ott in 1987 [5], was used to measure the bread volume. The volume was calculated by subtracting the measured volume of rapeseed mustard seed needed to fill an empty container and fill that same container that holds the bread. The baked bread weight 
and volume have also been measured following the same method.

\subsection{Proximate composition analysis}

Prepared banana flour and white flour bread were analyzed for moisture, protein, ash, crude fiber, and total sugar content by the method described in AOAC (2010) [6]. Carbohydrate content was determined by the subtraction method.

\subsection{Sensory evaluation of bread}

A semi-trained panel did the sensory evaluation. A 1-9-point hedonic rating test [7] was used to assess the degree of acceptability of color, flavor, texture, and overall acceptability of banana bread containing $5 \%, 10 \%$, and $15 \%$ banana flour. The score was arranged in a frequency table and statistically evaluated for variance analysis. However, if any variation existed, Duncan’s New Multiple Range Test procedure was followed.

\subsection{Statistical analysis}

All the analysis were conducted in triplicate, and the data were all subjected to ANOVA (analysis of variance) to determine significant differences among the various samples using statistical software SPSS (version 11.0 SPSS inc. Chicago, IL, USA)) at the 0.05 level.

\section{Results}

\subsection{Proximate composition of banana flour}

The proximate composition of the banana flour is presented in Table 2. Several authors also reported almost similar results. Gopalan et al. (1971) [8] and Kawamura (1967) [9] reported that banana flour contained $1.1 \%$ to $1.87 \%$ proteins, $0.016 \%$ to $0.4 \%$ fats, $19.33 \%$ to $25.8 \%$ carbohydrate, respectively. The variations in the results may be due to ripening quality, varietal differences, agroecological condition, fertilizer use, storage conditions, analysis methods, etc.

Table 2. Composition of banana flour

\begin{tabular}{cc}
\hline Component & Quantity (\%) \\
\hline Moisture & $14 \pm 0.95$ \\
Protein & $1.7 \pm 1.05$ \\
Fat & $0.4 \pm 0.56$ \\
Ash & $1.52 \pm 0.06$ \\
Crude fiber & $1.07 \pm 0.14$ \\
Total carbohydrate (\% by difference) & $81.31 \pm 0.98$ \\
\hline
\end{tabular}

\subsection{Proximate composition of banana bread}

The bread was prepared with $0 \%, 5 \%, 10 \%$, and $15 \%$ banana flour, and subsequently, the bread's proximate compositions were determined. The results of the analyses are shown in Table 3. The highest moisture content, 35.78\%, was found in the control sample compared to four different formulations. The moisture content was decreased gradually with the addition of banana flour, which possibly due to the contribution of solids content from banana flour. These results agreed with Viana et al. (2018) [10], where sliced bread was fortified with green banana flour. The protein percentage of banana flour bread declined marginally with the increase in banana flour. It may be that the banana flour contained a small amount of protein, and as the banana flour replaces wheat flour, the protein content of wheat flour was also substituted. Thus, adding banana flour to bread can decrease bread's protein content. Andrade et al. (2018) [11] also found this decrease in protein during banana-flour baking. The fat contents of different bread were 2.48 to $2.91 \%$, presented in Table 3. Though banana flour is not rich in fat but with wheat, the total fat content has increased. Oyetoro et al. (2016) [12] also reported that fat content decrease with green banana flour incorporation.

Table 3. Proximate composition of bread incorporated with banana flour

\begin{tabular}{ccccc}
\hline $\begin{array}{c}\text { Components } \\
(\%)\end{array}$ & Bread without Banana & Bread with 5\% Banana & Bread with 10\% Banana & Bread with 15\% Banana \\
Flour $\left(\mathrm{S}_{4}\right)$ & Flour $\left(\mathrm{S}_{3}\right)$ & Flour $\left(\mathrm{S}_{2}\right)$ & $31.95 \pm 1.33$ \\
\hline Moisture & $35.78 \pm 0.27$ & $33.55 \pm 1.05$ & $32.55 \pm 0.85$ & $7.86 \pm 0.85$ \\
Protein & $8.75 \pm 0.35$ & $8.5 \pm 0.04$ & $2.05 \pm 0.87$ & $2.91 \pm 1.05$ \\
Fat & $2.48 \pm 0.88$ & $2.60 \pm 1.02$ & $2.88 \pm 0.98$ & $1.8 \pm 0.88$ \\
Ash & $1.49 \pm 0.56$ & $1.59 \pm 0.26$ & $1.6 \pm 0.96$ & $1.42 \pm 0.74$ \\
Crude fiber & $0.9 \pm 0.04$ & $1.20 \pm 0.37$ & $1.3 \pm 0.16$ & $1.68 \pm 1.26$ \\
Total sugar & $1.87 \pm 0.26$ & $1.75 \pm 0.09$ & $1.72 \pm 0.87$ & $53.76 \pm 2.04$ \\
Carbohydrate & $50.60 \pm 0.19$ & $52.56 \pm 0.06$ & $53.32 \pm 1.22$ & \\
\hline
\end{tabular}


The highest ash content was found in the sample containing 15\% banana flour and lowest in control bread. The ash content increased with the increasing level of banana flour in the bread samples. High levels of ash in samples of bananas are representative of high mineral components. In banana flour bread, Khoozani et al. (2020) [13] also obtained greater quantities of ash. The crude fiber content in prepared bread ranged from $0.9 \%$ to $1.42 \%$ and increased by the change in banana flour. The crude fiber represents a variable fraction of dietary fiber and includes mostly the lignin, cellulose, and hemicellulose components. Several authors, Asif-Ul-Alam et al. (2014) [14] and Nasution et al. (2012) [15], also reported a similar increase in fiber content with increasing banana flour in the baked product. The sugar content of different bread samples was $1.68 \%$ to1.87\%, as shown in Table 3. The optimum level of sugar enhanced the bread's flavor, but more sugar content might be the cause of declining bread acceptability. The carbohydrate content of different bread samples varied from $51.493 \%$ to $54.175 \%$ (Table 3). The variations in carbohydrate contents among bread samples may result from the difference in protein, fat, ash, and moisture content of wheat flour and banana flour.

\subsection{Physical properties of banana bread}

Table 4 represents the physical characteristics of bread made of banana flour. Among the bread samples, the control bread had the highest volume. The volume of banana bread decreased with the increase of banana flour in the formulation due to the absence of gluten content in banana and lower bread volume. Furthermore, with the rising amount of bananas flour, the weight of bananas bread increased. This is possible because banana flour contained more mineral substances than wheat. The chemical study of banana bread indicates that the greater quantity of ash in banana bread predicts higher mineral material quantity in banana bread.

Table 4. Effect of various levels of banana flour on physical properties of banana bread

\begin{tabular}{ccccc}
\hline Physical Parameters & $\begin{array}{c}\text { Bread without } \\
\text { Banana Flour }\left(\mathrm{S}_{4}\right)\end{array}$ & $\begin{array}{c}\text { Bread containing 5\% } \\
\text { Banana Flour }\left(\mathrm{S}_{3}\right)\end{array}$ & $\begin{array}{c}\text { Bread containing 10\% } \\
\text { Banana Flour }\left(\mathrm{S}_{2}\right)\end{array}$ & $\begin{array}{c}\text { Bread containing 15\% } \\
\text { Banana Flour }\left(\mathrm{S}_{1}\right)\end{array}$ \\
\hline Volume (\% based on control) & 100 & 96.56 & 87.45 & 67.84 \\
Weight (\% based one control) & 100 & 101.8 & 102.4 & 103.01 \\
Specific Volume of Bread (\%) & 3.07 & 2.91 & 2.62 & 2.02 \\
\hline
\end{tabular}

The specific volumes of different bread varied from $2.02 \mathrm{cc} / \mathrm{gm}$ to $3.07 \mathrm{cc} / \mathrm{gm}$ and gradually decreased with increasing banana flour in bread formulation. Therefore, this negative relationship between banana flour and breed-specific bread volume can be seen, which agrees with observations in other studies [16].

\subsection{Sensory evaluation of banana bread}

Bread containing banana flour at various levels was subjected to sensory evaluation. The preference for color, texture, flavor, and overall acceptability of bread are given in Table 5. A significant $(\mathrm{p} \leq 0.05)$ difference was observed in crumb color, crumb texture, crust color, flavor, taste, and overall acceptability among the bread samples.

Table 5. Mean sensory scores of bread containing banana flour at various levels

\begin{tabular}{ccccccc}
\hline & & \multicolumn{3}{c}{ Mean Scores } & \\
Samples & Crumb color & Crumb texture & Crust color & Flavor & Taste & Overall Acceptability \\
\hline Control & $8.083 \mathrm{a}$ & $7.61 \mathrm{a}$ & $7.52 \mathrm{a}$ & $7.96 \mathrm{a}$ & $8.02 \mathrm{a}$ & $7.92 \mathrm{a}$ \\
$\mathrm{S}_{1}$ & $7.34 \mathrm{a}$ & $7.08 \mathrm{ab}$ & $7.22 \mathrm{ab}$ & $7.49 \mathrm{a}$ & $7.9 \mathrm{ab}$ & $7.41 \mathrm{a}$ \\
$\mathrm{S}_{2}$ & $7.16 \mathrm{~b}$ & $7.10 \mathrm{~b}$ & $7.03 \mathrm{~b}$ & $7.43 \mathrm{a}$ & $7.5 \mathrm{~b}$ & $7.28 \mathrm{a}$ \\
$\mathrm{S}_{3}$ & $6.76 \mathrm{~b}$ & $6.36 \mathrm{c}$ & $6.05 \mathrm{c}$ & $7.08 \mathrm{~b}$ & $6.8 \mathrm{c}$ & $6.28 \mathrm{~b}$ \\
\hline
\end{tabular}

$\mathrm{S}_{1}=$ Bread with $5 \%$ Banana flour, $\mathrm{S}_{2}=$ Bread with $10 \%$ banana flour, $\mathrm{S}_{3}=$ Bread with $15 \%$ banana flour.

The values are mean \pm SD. The mean with different superscripts in a row differ significantly $(\mathrm{p} \leq 0.05)$

The result showed that $5 \%$ of banana flour containing is the most acceptable in crumb color, crumb texture, and crust color. The acceptance of crumb and crust properties also decreases as the replacement degree increases. The sample S1 is most prominent with a mean 7.49 and 7.9 score, respectively, followed by the $S_{2}$ with a mean of 7.43 and 7.5 , and the S3 sample with an average score of 7.08 and 6.8, respectively. According to panelist score, sample $S_{1}$ was the most preferred in terms of overall acceptability, while $S_{3}$ is the least accepted, reflecting the addition of banana flour with wheat flour. These results are in accordance with the finding of Oyetoro et al. (2016) [12] and Mongi et al. (2011) [17].

\section{Conclusion}

This study has demonstrated that bread made from wheat flour incorporating banana powder had a higher amount of moisture, protein, fat, and minerals than bread from wheat flour only (i.e., control). It was observed that wheat flour 
could be substituted with banana flour to form banana flour bread up to $5 \%$ to achieve acceptable quality attributes. These findings will help generate technology that diversifies banana meal in the baking industry as a fortified formulation. However, more research should be carried out to determine how value-added ingredients in other food items are available.

\section{Conflict of interests}

The authors have no conflicts to declare.

\section{Acknowledgements}

The authors wish to express their gratitude towards Professor Dr. M. Nurul Islam and Professor Dr. Shams-Ud-Din, Department of FTRI, BAU, Mymensingh for their invaluable guidance and suggestions complete research work and writing up the findings of that research properly.

\section{References}

[1] Khoozani, A. A., Birch, J., and Bekhit, A. E. D. A. (2019). Production, application and health effects of banana pulp and peel flour in the food industry. Journal of food science and technology, 56(2): 548-559.

[2] Rajput, L. P., Haridas, P. R., and Shurpalekar, S. R. (1988). Use of unconventional protein sources in high protein biscuits. Indian Journal of Food Science and Technology, 25(1): 31-34.

[3] Martínez, M. M., Román, L., and Gómez, M. (2018). Implications of hydration depletion in the in vitro starch digestibility of white bread crumb and crust. Food Chem., 239: 295-303.

[4] Kent, N. L. and Evers, A. D. (1994). Bread-baking technology. Kent’s technology of cereals. 4ta Edición. Pergamon, Oxford, Inglaterra, 191-217.

[5] Ott, D. B. (1987). Applied Food Science Manual. Michigan State University. Pergamon Press, USA.

[6] AOAC. (2010). Official Methods of Analysis. Fourteenth edition. Association of Official Analytic Chemists. Washington, DC.

[7] Ranganna, S. (2007). Handbook of analysis and quality control for fruits and vegetables products. 3rd edition, Tata Mcgraw-Hills. Pp. 25-45.

[8] Gopalan, C., Sastri, R. B. V., and Balasubramanian, S. C. (1971). Nutritive value of Indian Foods. I. C. M. R., Hydrabad, India, referred by smith, R. G., Home Economist, MCC.

[9] Kawamura, S. (1967). Proceeding of International conference on soybean protein foods. Agricultural Research Service. U. S. Department of Agriculture, 3(2): 249.

[10] de Souza Viana, E., dos Santos Souza, A., Reis, R. C., and de Oliveira, V. J. D. S. (2018). Application of green banana flour for partial substitution of wheat flour in sliced bread. Semina: Ciências Agrárias, 39(6): 2399-2408.

[11] Andrade, B. A., Perius, D. B., Mattos, N. V., Luvielmo, M. M., and Mellado, M. S. (2018). Production of unripe banana flour (Musa spp) for application in whole wheat bread. Brazilian Journal of Food Technology, 21, e2016055. Epub November 13, 2017.

[12] Adebayo-Oyetoro, A. O., Ogundipe, O. O., and Adeeko, K. N. (2016). Quality assessment and consumer acceptability of bread from wheat and fermented banana flour. Food Science \& Nutrition, 4(3): 364-369.

[13] Khoozani, A., Kebede, B., Birch, J., and Bekhit, A. E. D. A. (2020). The Effect of Bread Fortification with Whole Green Banana Flour on Its Physicochemical, Nutritional and In Vitro Digestibility. Foods, 9(2): 152.

[14] Asif-Ul-Alam, S. M., Islam, M. Z., Hoque, M. M., \& Monalisa, K. (2014). Effects of drying on the physicochemical and functional properties of green banana (Musa sapientum) flour and baked product development. American Journal of Food Science and Technology, 2(4): 128-133.

[15] Nasution, Z., Lim, R. Y., and Wan Hafiz, W. Z. S. (2012). Banana peel flour: an alternative ingredient for wholemeal bread. In UMT 11th International Annual Symposium on Sustainability Science and Management. 09th-11th July (2012): 682-687.

[16] Segundo, C., Román, L., Lobo, M., Martinez, M. M., and Gómez, M. (2017). Ripe banana flour as a source of antioxidants in layer and sponge cakes. Plant Foods for Human Nutrition, 72(4): 365-371.

[17] Mongi, R. J., B. K. Ndabikunze, B. E. Chove, P. Mamiro, C. C. Ruhembe, and J. G. Ntwenya. (2011). Proximate composition, bread characteristics and sensory evaluation of cocoyam-wheat composite breads. Afr. J. Food Agric. Nutr. Dev., 11: 1-14. 